\title{
Taking time to twist a continent-Multistage origin of the New Zealand orocline
}

\author{
S. Lamb ${ }^{1}$ and N. Mortimer ${ }^{2}$ \\ ${ }^{1}$ Institute of Geophysics, Victoria University of Wellington, Wellington 6140, New Zealand \\ ${ }^{2}$ GNS Science, Dunedin 9016, New Zealand
}

\begin{abstract}
In New Zealand, a giant coherent " $Z$ " shape is defined by several curvilinear pre-Cenozoic basement terranes that extend across Zealandia for $>1500 \mathbf{~ k m}$ along strike. It is widely assumed that this curvature was the result of bending during the Neogene, which together with $\sim 450 \mathrm{~km}$ of dextral displacement on the Alpine fault accommodated a total of $\sim 750 \mathrm{~km}$ of dextral shear through the New Zealand plate boundary zone between the Australian and Pacific plates. This would make it a very simple form of orocline. In fact, we show that its development was surprisingly complex and protracted, with a composite origin. Its western and southern parts were bent as much as $70^{\circ}$ in the Mesozoic. In the Late Cretaceous, the already bent terranes were offset sinistrally by $\sim 250 \mathrm{~km}$ along the cross-cutting proto-Alpine fault, which acted as a transform to the rift between East and West Antarctica. Since the Eocene, and after Zealandia had completely separated from Antarctica, the two sides of the Alpine fault have undergone $45^{\circ}$ of relative plate rotation, further bending the terranes. However, the eastern part of what appears today to be the same oroclinal structure has been created entirely since the Eocene, and mainly during the Neogene phase of dextral shear through the plate boundary, with large-scale internal bending and shortening. We suggest that multistage and composite evolutions may be typical features of oroclines, which would be difficult to unravel without a rich tectonic and plate motion database, such as that available for the New Zealand region.
\end{abstract}

\section{INTRODUCTION}

Curvilinear mountain belts and metamorphic terranes are ubiquitous in the continents, but their origins commonly remain largely enigmatic, with multiple hypotheses for their mechanisms of formation (Platt et al., 1995; Roperch et al., 2006; Johnston et al., 2013; Rosenbaum, 2014). If the curvature has been created or enhanced by subsequent bending, then these features are called oroclines (Carey, 1955).

The timing and mechanism for creating the curvature of New Zealand's Paleozoic-Mesozoic basement terranes and batholiths (Fig. 1) have long been the subject of speculation. Prior to plate tectonic theory, it was widely believed that bending of the terranes, together with the observed $\sim 450 \mathrm{~km}$ dextral offset across the Alpine fault, occurred in the Mesozoic.

With the development of plate tectonic theory and the identification of oceanic magnetic anomalies around New Zealand (Sutherland, 1999; Cande and Stock, 2004; Barker et al., 2008; Croon et al., 2008), it has become clear that there has been $\sim 750 \mathrm{~km}$ of dextral displacement through Zealandia since the latest Oligocene (the past 25 m.y.). Evidence for post-Oligocene bending comes from numerous paleomagnetic observations on Neogene rocks along the Hikurangi margin, creating the eastern part of a "Z"-shaped orocline (Figs. 1B and 1D; see Lamb [2011] for a review of these data). However, much sparser paleomagnetic data for the western and southern parts of what appeared to be the same structure, in western North and South Islands, initially indicated a more complex pattern of rotation, with large-magnitude Cenozoic rotation of the basement terranes at some sites, but no rotation relative to the Australian plate at others (Fig. 1B; summarized in Lamb et al. [2016]).

Interpretations of the development of the New Zealand oroclinal structure have generally fallen into two classes, depending on which set of paleomagnetic data has been regarded as reliable: (1) in some models, Neogene rotation is minimal (Fig. 1B; Sutherland, 1999; Nicol et al.,
2007; Seebeck et al., 2014); (2) whereas in more widely accepted models, significant Neogene rotation occurs in most parts of the orocline (Fig. 1B; Kamp, 1987; Walcott, 1987; Sutherland, 1999; King, 2000; Rowan and Roberts, 2008; Lamb, 2011). The second class of models is supported by the progressive rotation of the seismically fast mantle anisotropy direction in a zone $>300 \mathrm{~km}$ wide toward a central axis along the Alpine fault, interpreted in terms of distributed shear and rotation in the New Zealand plate boundary zone (Moore et al., 2002; Collins and Molnar, 2014). A common assumption is that at the inception of the New Zealand plate boundary zone, ca. $45 \mathrm{Ma}$, the basement terranes were contiguous and nearly straight across Zealandia, providing markers for the total Cenozoic displacement (Fig. 1B).

In this study, we bring together a wide range of geological and geophysical observations to show that (1) the orocline can be divided into separate eastern, western, and southern parts that developed independently, and (2) the terranes were not contiguous across Zealandia in the early Cenozoic. Building on old and new ideas about the evolution of the New Zealand orocline (Kamp, 1987; Lamb, 2011; Mortimer, 2014, 2018; Lamb et al., 2016), we present a new (and testable) hypothesis for the tectonic development of the New Zealand orocline involving a longer and complex multistage evolution (Figs. 2 and 3).

\section{DATA FOR TECTONIC ROTATION IN NEW ZEALAND}

Evidence for vertical-axis tectonic rotations in New Zealand mainly comes from paleomagnetic analyses of nearly 90 localities in fine-grained and marine sedimentary sequences, including extensive magnetostratigraphic profiling of both normal and reversed magnetizations, exposed throughout New Zealand (Figs. 1B and 1D; Table S1 in the

CITATION: Lamb, S., and Mortimer, N., 2020, Taking time to twist a continent-Multistage origin of the New Zealand orocline: Geology, v. 49, p. https://doi.org/10.1130/G47805.1 


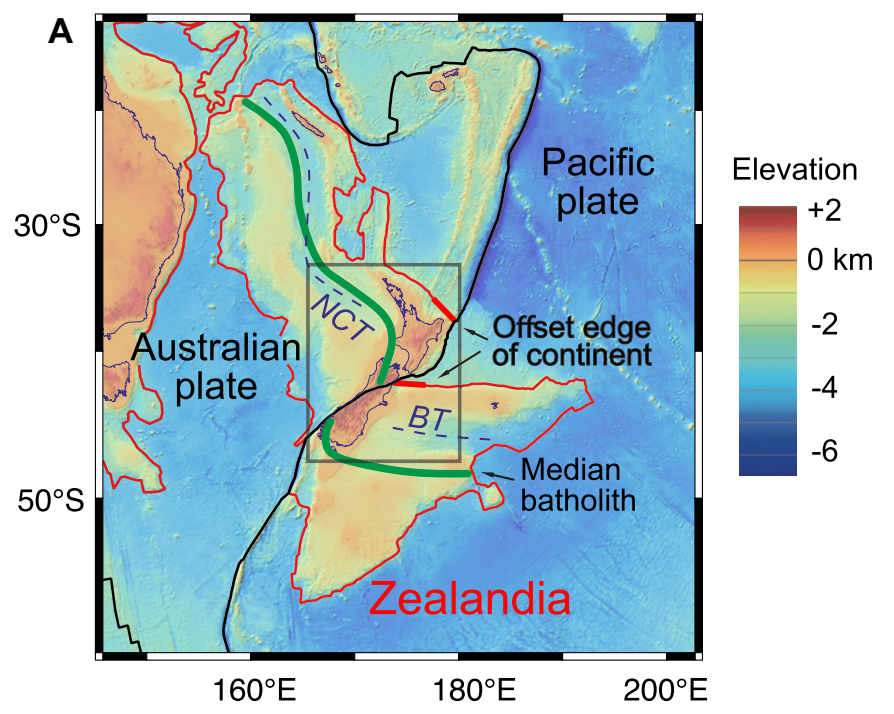

\section{D \\ Southern hinge of eastern part of orocline}

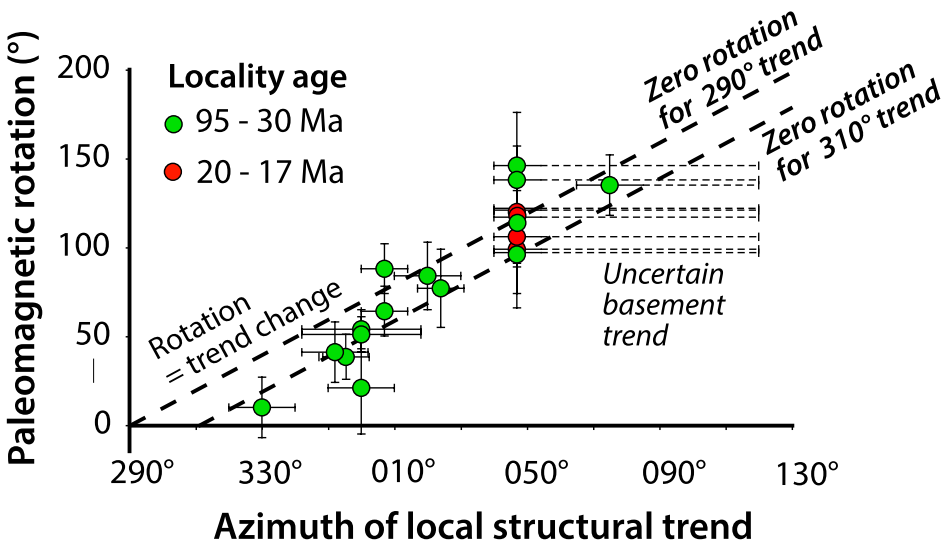

B

C
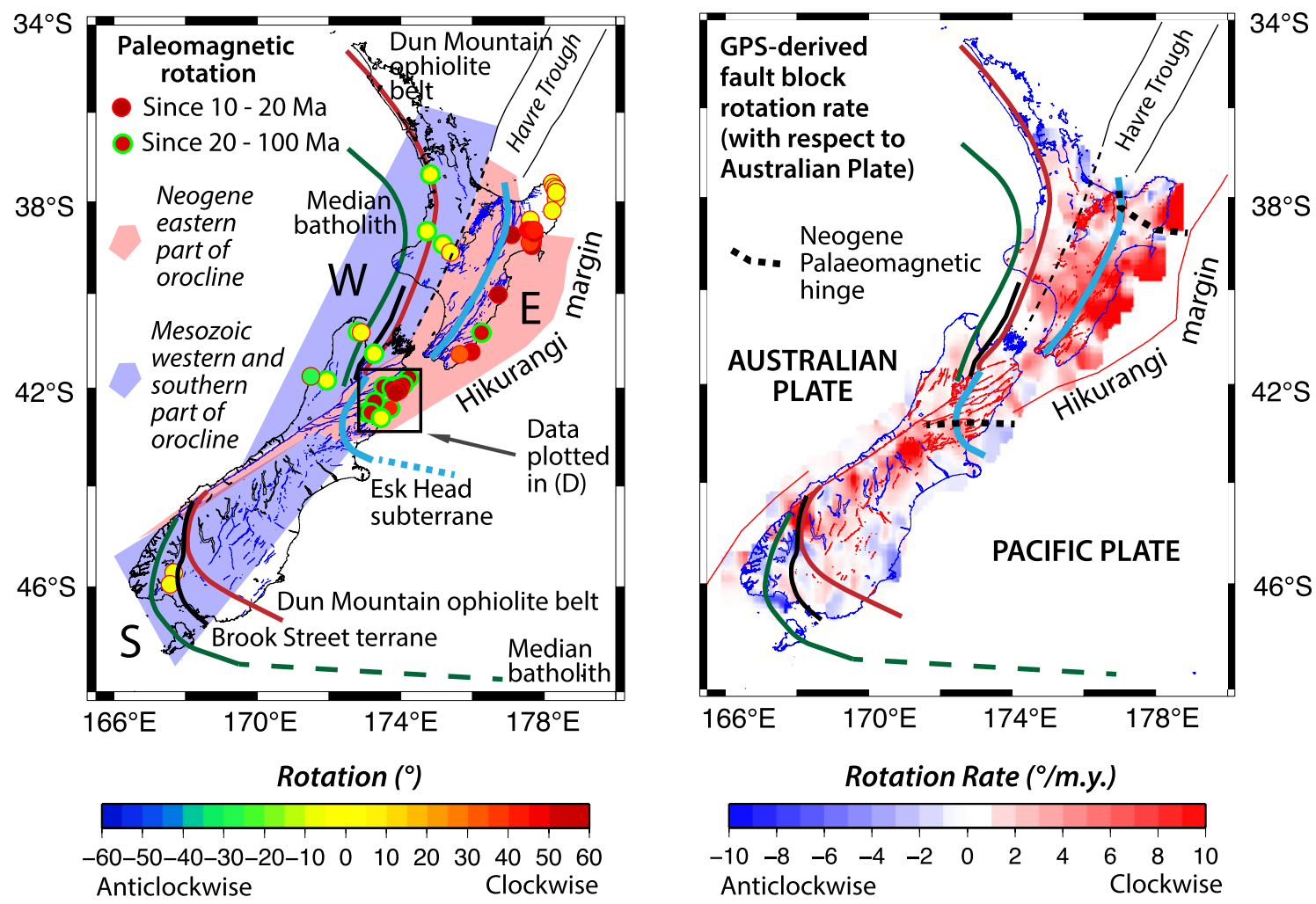

Figure 1. (A) Topography and bathymetry of Zealandia showing obliquely convergent boundary between the Pacific and Australian plates (black line), active since ca. $45 \mathrm{Ma}$ and passing through New Zealand. Note the offshore zones of thinner crust (axes shown as dashed lines) in the New Caledonian (NCT) and Bounty (BT) Troughs, and overall "Z"-shaped basement trend (from Mortimer et al., 2020). Thick green line shows structural trend of the Median batholith terrane; red lines enclose regions of continental crust. (B) Paleomagnetic and structural data for New Zealand (see box in A for location, and Table S1 [see footnote 1] for paleomagnetic data), with bent Permian and Mesozoic basement terranes, defining the western (W) and southern (S) (blue) and eastern (E) (red) parts of the New Zealand orocline. Circle color indicates magnitude of rotation. Thick coloured lines show the trends of basement terranes, labelled in the figure. (C) Fault block rotation rate (see text) from GPS-derived strain rate field; the Hikurangi margin shows the highest active and long-term rates of rotation. Thick colour lines show trends of basement terranes, as in B. Note the northern and southern hinges in Hikurangi margin (eastern part of orocline), shown as thick dashed black lines, accommodating $\sim 90^{\circ}$ of Neogene bending relative to the Pacific plate, and marked by changes in structure trend. (D) Paleomagnetic rotation data (with error bars defining $95 \%$ confidence limits for both rotation and structural trend) in Late Cretaceous to Neogene sedimentary and volcanic rocks around the southern hinge (see box in B), plotted against local structural trend (adapted from Lamb, 2011). 
A

$20 \mathrm{Ma}$

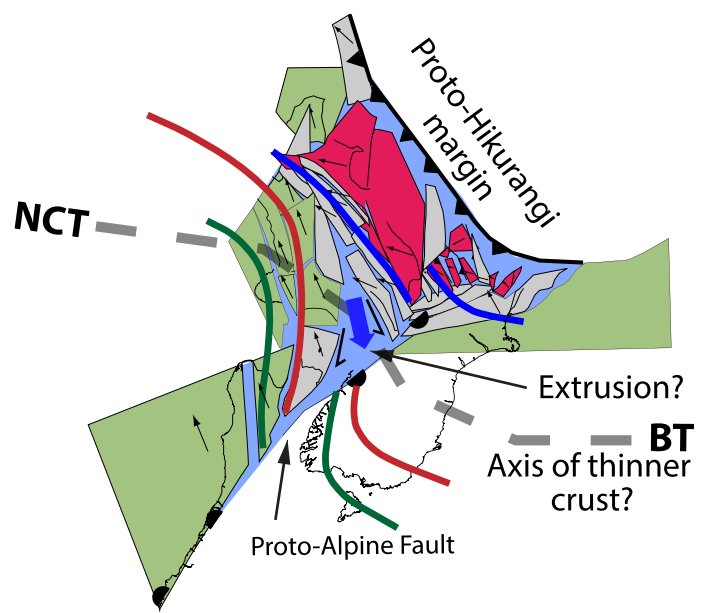

- Esk Head subterrane
Dun Mountain ophiolite belt
- Median batholith
B $\quad 11 \mathrm{Ma}$

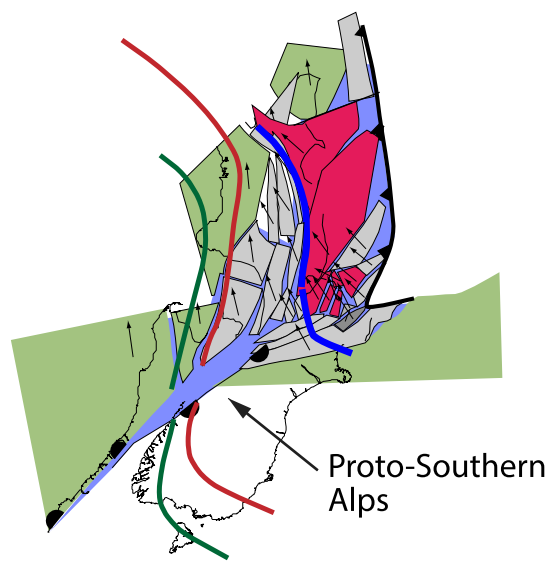

1. Piercing points

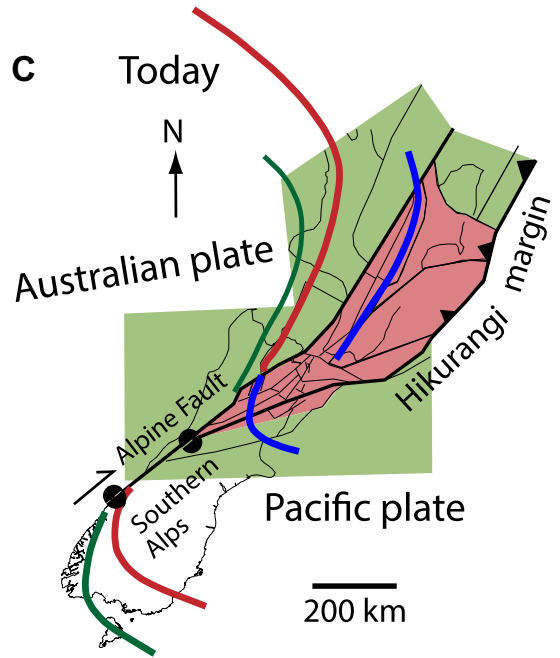

Area of crust lost due to shortening, underthrusting and extrusion since reconstruction

Figure 2. Series of block reconstructions of the New Zealand plate boundary zone, based on the finite rotation poles of Cande and Stock (2004) and paleomagnetic data (summarized in Lamb [2011]), together with the pattern of Cenozoic faulting (modified from Lamb, 2011; Lamb et al., 2015). Thick red, green, and blue lines show trends of major basement terranes (see figure key). Note the piercing points that match today along the Alpine fault. Red shows blocks that have rotated $>60^{\circ}$ clockwise since ca. $25 \mathrm{Ma}$, whereas green shows blocks that have rotated at the same rate as either the Pacific plate (treated as fixed) or the Australian plate. Prominent basement terranes already had $\sim 250 \mathrm{~km}$ sinistral offset prior to $20 \mathrm{Ma}$. Note the triangular area of the blue crust, increasing in width toward the south, which was consumed as the Hikurangi margin rotated clockwise, either through crustal shortening and thickening or southward extrusion. This region lies opposite the thickest crust in the Southern Alps today, and also on a projection (heavy dashed line) of thinner crust of the New Caledonian Trough (NCT) and Bounty Trough (BT) rift zones (see Fig. 1A).

Supplemental Material $\left.{ }^{1}\right)$. These show regional progressive clockwise rotation of the Hikurangi margin of as much as $\sim 90^{\circ}$ (and locally $120^{\circ}$ ) relative to the Pacific plate in the past 25 m.y. (although there has been disagreement about the exact timing of rotation, depending on the interpretation of remagnetizations; see discussion in Lamb [2011] and Rowan and Roberts [2008]). This defines the eastern part of the orocline (Kamp, 1987; Walcott, 1987), which is bounded to the north and south by two "hinges" where there is a marked change in both structural trend and amount of paleomagnetically observed vertical-axis rotation (Figs. 1B and 1D; Lamb, 2011). In contrast, reanalysis of demagnetization data from Paleogene to Miocene, mainly marine sedimentary sequences along the western side of both North and South Islands (Fig. 1A) have shown that the large clockwise tectonic rotations apparent in some sites were spurious and due to magnetic overprints. The end-point primary magnetizations for 13 localities confirm no significant tectonic rotation since the Eocene relative to

${ }^{1}$ Supplemental Material. Table of published paleomagnetic data used in this study. Please visit https://doi.org/10.1130/GEOL.S.12837773 to access the supplemental material, and contact editing@ geosociety.org with any questions. the nearest stable plate, depending on which side of the Alpine fault the samples are located (summarized in Lamb et al. [2016]). However, there has been $\sim 45^{\circ}$ of relative plate rotation across the Alpine fault since the inception of the plate boundary at ca. $45 \mathrm{Ma}$ (Cande and Stock, 2004). This leaves $\sim 70^{\circ}$ (or $\sim 60 \%$ of the maximum $115^{\circ}$ ) of the observed bending between the western (western North Island, and northwest Nelson on the northern South Island) and southern parts (Fiordland, southern South Island) of the orocline as a preexisting feature, prior to the Cenozoic development of the New Zealand plate boundary zone (Fig. 1B; Table S1; summarized in Lamb [2011] and Lamb et al. [2016]).

Lamb et al. (2016) demonstrated that the known Cenozoic deformation in the western and southern parts of the orocline is insufficient to accommodate Neogene clockwise rotation of $>10^{\circ}$ of the basement terranes here, relative to either the Pacific or Australian plates, except in a narrow zone $<10 \mathrm{~km}$ from the Alpine fault. This confirms that Cenozoic relative plate motion through Zealandia was mainly taken up by $\sim 700 \mathrm{~km}$ of dextral displacement on the Alpine fault, reversing a $\sim 250 \mathrm{~km}$ sinistral displacement on a proto-Alpine fault that occurred in the late Cretaceous (Figs. 2 and 3). Metamorphic and structural data from the
New Zealand region also point to the possibility of pre-Eocene shear through New Zealand (Mortimer, 2018).

The pattern of short-term deformation indicated by both GPS and Quaternary fault slip data (Lamb, 2011; Lamb et al., 2015) indicates that rotation of the eastern part of the orocline, along the Hikurangi margin, is active today. The GPS-derived strain rates of active deformation indicate mainly clockwise vertical-axis rotation of fault blocks along the Hikurangi margin at $0^{\circ}-8^{\circ} / \mathrm{m}$.y. relative to the Australian plate (Fig. 1C), calculated using the floating block model of Lamb (1987) for needle-shaped blocks aligned parallel to major active faults. This compares with a total regional Neogene clockwise rotation in the eastern orocline of $\sim 60^{\circ}$ relative to the Australian plate $\left(\sim 90^{\circ}\right.$ relative to the Pacific plate). Thus, paleomagnetically observed clockwise rotations could easily be achieved in 20 m.y. (Fig. 1B), although the rate of rotation has accelerated toward the present, associated with the initiation of back-arc extension in the Havre Trough and Central Volcanic Zone in the past 5 m.y. (Walcott, 1987; Lamb, 2011). Importantly, the western and southern parts of the orocline are associated with very low Quaternary strain and rotation rates (Fig. 1C), strongly suggesting they are older features that are not active today. 


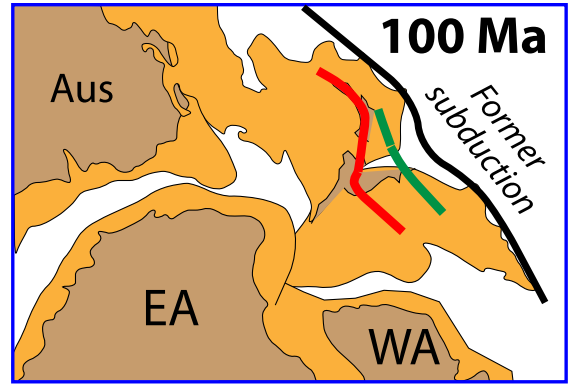

Initial Gondwana breakup
B

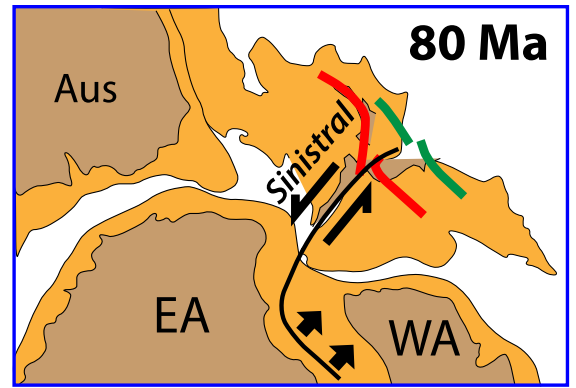

Rifting between E and W Antarctica

D

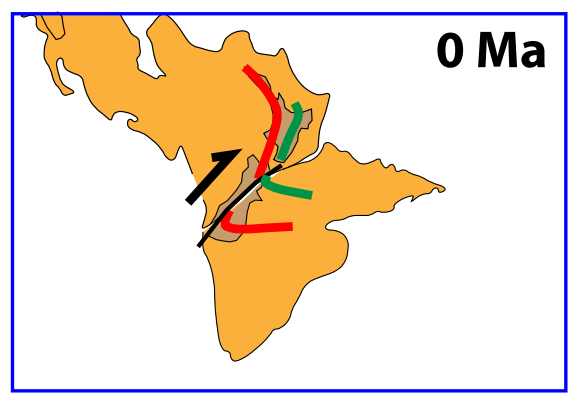

New Zealand orocline today

Figure 3. Schematic evolution of the New Zealand orocline. (A) Zealandia as part of the postsubduction margin of Gondwana, where a series of linear accreted terranes started to undergo extensional deformation. Thick colored lines show structural trends of the basement terranes forming the Dun Mountain ophiolite belt (red) and Esk Head subterrane (green). Brown and orange colored regions show emergent or submerged continental crust, respectively. (B) Between 100 and $80 \mathrm{Ma}$, rifting between East (EA) and West (WA) Antarctica was accommodated by $\sim 250 \mathrm{~km}$ of sinistral motion on the transform through Zealandia, offsetting already-bent basement terranes. Aus-Australia. (C) Subsequently, Zealandia rifted away from Antarctica, and a new plate boundary between the Pacific and Australian plates formed at ca. $45 \mathrm{Ma}$. By ca. $20 \mathrm{Ma}$, dextral shear through Zealandia had initiated, resulting in clockwise rotation of the Hikurangi margin and basement terranes in the eastern part of the orocline. (D) Modern-day configuration.

\section{KINEMATIC MODELS OF CENOZOIC TECTONIC ROTATION}

The central tectonic problem in understanding the development of the New Zealand orocline is accounting for the existence of as much as $70^{\circ}$ of bending in the western and southern parts prior to the Cenozoic (Fig. 1B), but largescale Neogene rotation of as much as $120^{\circ}$ in the adjacent eastern part. A critical constraint is the relative plate motion, from the breakup of Gondwana in the Cretaceous to the development of the New Zealand plate boundary zone in the Cenozoic (Sutherland, 1999; Cande and Stock, 2004; Barker et al., 2008; Croon et al., 2008). Figure 2 shows Cenozoic reconstructions of onshore New Zealand using paleomagnetic data in the context of tectonic blocks, defined by the geometry of major faults.

The plate reconstructions, together with the absence of large-scale Cenozoic bending in the western and southern parts of the orocline, require a sinistral offset of $\sim 250 \mathrm{~km}$ across the proto-Alpine fault at the inception of the plate boundary zone at ca. $45 \mathrm{Ma}$ (Fig. 3; Lamb et al., 2016). In addition, there was sub- stantial shortening in the central part of the orocline, increasing to the south and coeval with the clockwise rotation of the Hikurangi margin (Lamb, 2011). The maximum shortening is $\sim 150 \mathrm{~km}$, or $50 \%$ shortening, as a result of deformation between 20 and $10 \mathrm{Ma}$ (Fig. 2C). This created the thick crust and rugged relief beneath essentially undeformed southern behind-subduction basins (King, 2000). The required shortening is significantly reduced compared to previous models (see Lamb, 2011) because of the initial sinistral offset of the terranes across the proto-Alpine fault prior to the Neogene. However, the 30-40-km-thick crust here is still too thin to account for this shortening by vertical pure shear if the initial crustal thickness was $\sim 28 \mathrm{~km}$, typical of onshore New Zealand at the edges of the plate boundary zone (Holt and Stern, 1994; Scherwath et al., 2003; Tozer et al., 2017).

We suggest that the crust in the region of intense Miocene shortening, where Neogene bending is at a maximum, was originally relatively thin (i.e., $20-25 \mathrm{~km}$ ), forming part of a zone of crustal thinning in the onshore exten- sions of the Late Cretaceous New Caledonia and Bounty Troughs, which are prominent rift features in offshore Zealandia (Figs. 1A and 2C; Mortimer, 2014). In addition, significant southward extrusion (as much as $100 \mathrm{~km}$ between 20 and $10 \mathrm{Ma}$; or $\leq 10 \mathrm{~mm} / \mathrm{yr}$ ) of crust toward the proto-Southern Alps along conjugate strike-slip faults would have accommodated shortening without local crustal thickening (Fig. 2C)this would have led to early Neogene crustal thickening beneath the Southern Alps, helping to explain the substantial crustal root here, as much as $50 \mathrm{~km}$ thick, and Miocene exhumation of metamorphic rocks along the Alpine fault (Lamb et al., 2015; Ring et al., 2019).

In the Late Cretaceous, Zealandia lay on the margin of Gondwana, joined to Antarctica so that the proto-Alpine fault intersected the crustal boundary between East and West Antarctica (Fig. 3; Lawver et al., 1992; Cande and Stock, 2004; Lamb et al., 2016; Tinto et al., 2019). Thus, the proto-Alpine fault was optimally positioned as a transform during Late Cretaceous rifting between East and West Antarctica (Fitzgerald, 2002; Siddoway et al., 2004), accommodating extension with $\sim 250 \mathrm{~km}$ of sinistral displacement through Zealandia (Fig. 3). Both the onshore geology in New Zealand (e.g., Kimbrough et al., 1994) and seafloor magnetic anomalies between Antarctica and Zealandia (Cande and Stock, 2004) constrain the sinistral motion to the period between 100 and $80 \mathrm{Ma}$ (Fig. 3).

Our proposed structural evolution indicates that bending of the western and southern parts of the New Zealand orocline goes back at least to the Cretaceous (Fig. 3). This is supported by the detailed geometry of the basement terranes, which show a marked widening in across-strike thickness toward the southeast of the intervening accreted material between the younger Cretaceous Esk Head subterrane and the Median batholith (Figs. 1B and 3), and at least $60^{\circ}$ of bending of the Brook Street terrane occurred prior to the Late Cretaceous, with possibly some bending prior to the Jurassic or Triassic (Fig. 1A; Kamp, 1987; Lamb et al., 2016). Indeed, such bending during accretion along complex margins has been simulated in numerical models of subduction and arc collision (Moresi et al., 2014). In addition, Mortimer (2014) proposed that the western and southern parts of the orocline were enhanced during the Late Cretaceous Gondwana breakup with the opening of the New Caledonia and Bounty Troughs. This evolution also requires reinterpretation of the mantle lithosphere seismic anisotropy fabric, which cannot now be explained in terms of distributed deformation in the New Zealand plate boundary zone during the Cenozoic (Moore et al., 2002; Collins and Molnar, 2014), but other explanations related to underthrusting of the Australian plate are possible (Lamb et al., 2015, 2016). 
The long-lived, multistage, composite evolution of the New Zealand orocline, finally resulting in a seemingly simple tight and offset " $Z$ " bend in all the basement terranes, may serve as a useful framework for understanding the potential complexity of oroclinal bending in other deforming zones. Thus, oroclines likely form as part of a longer tectonic evolution of a convergent plate margin, from an initial configuration related to the geometry of accretion during subduction to subsequent reactivation during changes in relative plate motion. Unravelling all of this requires well-constrained plate reconstructions in combination with a rich database of paleomagnetic observations.

\section{ACKNOWLEDGMENTS}

We thank Stephen Johnston and an anonymous reviewer for insightful reviews that helped to improve the manuscript.

\section{REFERENCES CITED}

Barker, D.H.N., Wood, R., and Sutherland, R., 2008, Transform and rift structure of Paleogene crust near Resolution Ridge, Tasman Sea, southwest New Zealand: Geochemistry Geophysics Geosystems, v. 9, Q07024, https://doi .org/10.1029/2007GC001887.

Cande, S.C., and Stock, J.M., 2004, Cenozoic reconstructions of the Australia-New Zealand-South Pacific sector of Antarctica, in Exon, N.F., et al., eds., The Cenozoic Southern Ocean: Tectonics, Sedimentation, and Climate Change Between Australia and Antarctica: American Geophysical Union Geophysical Monograph 151, p. 5-17, https://doi.org/10.1029/151GM02.

Carey, S.W., 1955, The orocline concept in geotectonics-Part I: Papers and Proceedings of the Royal Society of Tasmania, v. 89, p. 255-288.

Collins, J.A., and Molnar, P., 2014, Pn anisotropy beneath the South Island of New Zealand and implications for distributed deformation in continental lithosphere: Journal of Geophysical Research: Solid Earth, v. 119, p. 7745-7767, https://doi.org/10.1002/2014JB011233.

Croon, M.B., Cande, S.C., and Stock, J.M., 2008, Revised Pacific-Antarctic plate motions and geophysics of the Menard Fracture Zone: Geochemistry Geophysics Geosystems, v. 9, Q07001, https://doi.org/10.1029/2008GC002019.

Fitzgerald, P., 2002, Tectonics and landscape evolution of the Antarctic plate since the breakup of Gondwana, with an emphasis on the West Antarctic Rift System and the Transantarctic Mountains: Royal Society of New Zealand Bulletin, v. 35, p. 453-469.

Holt, W.E., and Stern, T.A., 1994, Subduction, platform subsidence, and foreland thrust loading: The late Tertiary development of Taranaki Basin, New Zealand: Tectonics, v. 13, p. 1068-1092, https:// doi.org/10.1029/94TC00454.

Johnston, S.T., Weil, A.B., and Gutiérrez-Alonso, G., 2013, Oroclines: Thick and thin: Geological Society of America Bulletin, v. 125, p. 643-663, https://doi.org/10.1130/B30765.1.

Kamp, P.J.J., 1987, Age and origin of the New Zealand Orocline in relation to Alpine Fault movement:
Journal of the Geological Society, v. 144, p. 641652, https://doi.org/10.1144/gsjgs.144.4.0641.

Kimbrough, D.L., Tulloch, A.J., Coombs, D.S., Landis, C.A., Johnston, M.R., and Mattinson, J.M. 1994, Uranium-lead zircon ages from the median tectonic zone, New Zealand: New Zealand Journal of Geology and Geophysics, v. 37, p. $393-$ 419, https://doi.org/10.1080/00288306.1994.95 14630.

King, P.R., 2000, Tectonic reconstructions of New Zealand: 40 Ma to the present: New Zealand Journal of Geology and Geophysics, v. 43, p. 611-638, https://doi.org/10.1080/00288306.2000.9514913.

Lamb, S.H., 1987, A model for tectonic rotation about a vertical axis: Earth and Planetary Science Letters, v. 84, p. 75-86, https://doi .org/10.1016/0012-821X(87)90178-6.

Lamb, S., 2011, Cenozoic tectonic evolution of the New Zealand plate-boundary zone: A paleomagnetic perspective: Tectonophysics, v. 509, p. 135 164, https://doi.org/10.1016/j.tecto.2011.06.005.

Lamb, S., Smith, E., Stern, T., and Warren-Smith, E., 2015, Continent-scale strike-slip on a low-angle fault beneath New Zealand's Southern Alps: Implications for crustal thickening in oblique collision zones: Geochemistry Geophysics Geosystems, v. 16, p. 3076-3096, https://doi .org/10.1002/2015GC005990.

Lamb, S., Mortimer, N., Smith, E., and Turner, G., 2016, Focusing of relative plate motion at a continental transform fault: Cenozoic dextral displacement $>700 \mathrm{~km}$ on New Zealand's Alpine Fault, reversing $>225 \mathrm{~km}$ of Late Cretaceous sinistral motion: Geochemistry Geophysics Geosystems, v. 17, p. 1197-1213, https://doi .org/10.1002/2015GC006225.

Lawver, L.A., Gahagan, L.M., and Coffin, M.F., 1992, The development of paleoseaways around Antarctica, in Kennett, J.P., and Warkne, D.A., eds., The Antarctic Paleoenvironment: A Perspective on Global Change-Part One: American Geophysical Union Antarctic Research Series 56, p. 7-30, https://doi.org/10.1029/AR056p0007.

Moore, M., England, P., and Parsons, B., 2002, Relation between surface velocity field and shear wave splitting in the South Island of New Zealand: Journal of Geophysical Research: Solid Earth, v. 107, B9, https://doi.org/10.1029/200 0JB000093.

Moresi, L., Betts, P.G., Miller, M.S., and Cayley, R.A., 2014, Dynamics of continental accretion: Nature, v. 508 , p. 245-248, https://doi .org/10.1038/nature13033.

Mortimer, N., 2014, The oroclinal bend in the South Island, New Zealand: Journal of Structural Geology, v. 64, p. 32-38, https://doi.org/10.1016/ j.jsg.2013.08.011.

Mortimer, N., 2018, Evidence for a pre-Eocene proto-Alpine Fault through Zealandia: New Zealand Journal of Geology and Geophysics, v. 61, p. 251-259, https://doi.org/10.1080/0 0288306.2018.1434211.

Mortimer, N., Smith Lyttle, B., and Black, J., 2020, Tectonic map of Te Riu-a-Māui / Zealandia: GNS Science Poster 8, scale 1:8,500,000, https://doi .org/10.21420/M90C-5J03.

Nicol, A., Mazengarb, C., Chanier, F., Rait, G., Uruski, C., and Wallace, L., 2007, Tectonic evolution of the active Hikurangi subduction margin, New Zealand, since the Oligocene: Tectonics, v. 26 , TC4002, https://doi.org/10.1029/2006TC002090.
Platt, J., Allerton, S., Kirker, A., and Platzman, E., 1995, Origin of the western Subbetic arc (South Spain): Palaeomagnetic and structural evidence: Journal of Structural Geology, v. 17, p. 765-775, https://doi.org/10.1016/0191-8141(94)00110-L.

Ring, U., Glodny, J., Angiboust, S., Little, T., and Lang, K.A., 2019, Middle to Late Miocene age for the end of amphibolite-facies mylonitization of the Alpine Schist, New Zealand: Implications for onset of transpression across the Alpine Fault: Tectonics, v. 38, p. 4335-4359, https:// doi.org/10.1029/2019TC005577.

Roperch, P., Sempere, T., Macedo, O., Arriagada, C., Fornari, M., Tapia, C., García, M., and Laj, C., 2006, Counterclockwise rotation of late EoceneOligocene fore-arc deposits in southern Peru and its significance for oroclinal bending in the central Andes: Tectonics, v. 25, TC3010, https://doi .org/10.1029/2005TC001882.

Rosenbaum, G., 2014, Geodynamics of oroclinal bending: Insights from the Mediterranean: Journal of Geodynamics, v. 82, p. 5-15, https://doi .org/10.1016/j.jog.2014.05.002.

Rowan, C.J., and Roberts, A.P., 2008, Widespread remagnetizations and a new view of Neogene tectonic rotations within the Australia-Pacific plate boundary zone, New Zealand: Journal of Geophysical Research, v. 113, B03103, https:// doi.org/10.1029/2006JB004594.

Scherwath, M., Stern, T., Davey, F., Okaya, D., Holbrook, W.S., Davies, R., and Kleffmann, S., 2003, Lithospheric structure across oblique continental collision in New Zealand from wide-angle $\boldsymbol{P}$ wave modeling: Journal of Geophysical Research, v. 108, 2566, https://doi .org/10.1029/2002JB002286.

Seebeck, H., Nicol, A., Villamor, P., Ristau, J., and Pettinga, J., 2014, Structure and kinematics of the Taupo Rift, New Zealand: Tectonics, v. 33, p. 11781199, https://doi.org/10.1002/2014TC003569.

Siddoway, C.S., Baldwin, S.L., Fitzgerald, P.G., Fanning, C.M., and Luyendyk, B.P., 2004, Ross Sea mylonites and the timing of intracontinental extension within the West Antarctic rift system: Geology, v. 32, p. 57-60, https://doi.org/10.1130/ G20005.1.

Sutherland, R., 1999, Cenozoic bending of New Zealand basement terranes and Alpine Fault displacement: A brief review: New Zealand Journal of Geology and Geophysics, v. 42, p. 295-301, https://doi.org/10.1080/00288306.1999.9514846.

Tinto, K.J., et al., 2019, Ross Ice Shelf response to climate driven by the tectonic imprint on seafloor bathymetry: Nature Geoscience, v. 12, p. 441449, https://doi.org/10.1038/s41561-019-0370-2.

Tozer, B., Stern, T.A., Lamb, S.L., and Henrys, S.A., 2017, Crust and upper-mantle structure of Wanganui Basin and southern Hikurangi margin, North Island, New Zealand as revealed by active source seismic data: Geophysical Journal International, v. 211 , p. 718-740, https://doi .org/10.1093/gji/ggx303.

Walcott, R.I., 1987, Geodetic strain and the deformational history of the North Island of New Zealand during the late Cainozoic: Philosophical Transactions of the Royal Society of London: Series A, Mathematical and Physical Sciences, v. 321, p. 163-181, https://doi .org/10.1098/rsta.1987.0009.

Printed in USA 